\title{
Intertextuality in Legislative and Private Legal Texts
}

\author{
Dana Abdul Rahman Trabulsi (Corresponding author) \\ Department of Foreign Languages, College of Arts, Humanities and Social Sciences \\ University of Sharjah, Sharjah, United Arab Emirates \\ E-mail: thepearl_50@hotmail.com
}

\begin{abstract}
Sane Yagi
Department of Foreign Languages, College of Arts, Humanities and Social Sciences

University of Sharjah, Sharjah, United Arab Emirates
\end{abstract}

\begin{abstract}
Abdulfattah Abu Ssaydeh
Department of Foreign Languages, College of Arts, Humanities and Social Sciences

University of Sharjah, Sharjah, United Arab Emirates
\end{abstract}

Received: January 1, 2021

Accepted: February 8, 2021

Published: February 28, 2021

doi:10.5296/ijl.v13i1.18177

URL: https://doi.org/10.5296/ijl.v13i1.18177

\begin{abstract}
Intertextuality has always been examined narrowly in the legal sphere despite its paramount significance to the legal translation analysis and pedagogy. For quite some time, the notion of intertextuality was deemed as a literary tool that contributed significantly to the literary works of infamous authors, novelists and poets. Post to a wealth of research to substantiate the omnipresence of intertextuality in other disciplines in general and in legal texts in particular, findings have restricted the notion of intertextuality to quite few phenomena such as citation, cross references, legal judgments, quotations and assimilation. This study, on the other hand, is an attempt to bring other implicit forms of intertextuality in legal written texts to light, through providing evidence-based generalizations about the different forms of intertextuality that are, deliberately or inadvertently, omnipresent in legislative and private legal texts. The notion of intertextuality was broadened to include recurrent legal terminologies and salient syntactic features in contractual agreements. The rhetorical organization of several legislative
\end{abstract}


texts, such as UAE Decree, UAE labor law and an executive order originated from the USA was also closely examined to establish the notion of intertextuality in the structure of such texts. The results revealed that contractual agreements share similar templates and rhetorical organization, and the same holds true for legislative texts. A set of legal terminologies were found to be commonly utilized in lease agreements, employment agreements and Power of attorneys despite their different origins. Finally, the uses of a number of syntactic features were rather remarkable in contractual agreements, such as the abundant use of modal verbs to express obligation and imply futurity.

Keywords: Genre, Intertextuality, Legislative texts, Private legal texts

\section{Introduction}

\subsection{Significance of the Problem}

Julia Kristeva first introduced intertextuality in 1966. She states "a mosaic of quotations; any text is the absorption and transformation of another" (p.37).Within this definition, intertextuality was employed as a process of using ideas, sentences, phrases, and words from previous works to enrich more recent works with profound concepts and sophisticated words. In many cases, intertextuality is a major contributor to literary works. A considerable number of poems, novels and plays are imbued with substantial portions of incorporated archaic words and texts that contributed significantly to the enrichment of a given literary text on different levels: semantically, lexically, syntactically and pragmatically.It did not take the notion a long time before it appeared in linguistics as one of the seven criteria of textuality proposed by R. de Beaugrande and W. Dressler (1994). Eventually, the term made it into Translation Studies and practice as it will be explained later. Be that as it may, intertextuality in legal texts, mainly in legislative and private legal texts, has always been examined cautiously and narrowly despite its paramount significance to the field of legal translation analysis and translation pedagogy. The notion of intertextuality in legal written texts has been restricted to several phenomena such as citations and quotations.

\subsection{Relevant Scholarship}

Within Translation Studies, "textuality" is a term that was fundamentally started by Beaugrande (1981) and Hatim and Mason (1997), to clear the way for the foundation of a solid model to standardize certain features that would shape a text. Texts are deemed to be the genuine utilization of language, as they are created for communicative purposes and point to associate the readership to the content. In order to produce a communicative text which maintains connectivity among all parties concerned (reader, writer and the text), seven standards of textuality must be fulfilled, otherwise, the text will be treated as a non-communicative text therefore, a non-text (Mikhchi, 2011). According to Beaugrande \& Dressler (1981), "the seven standards of textuality are cohesion, coherence, intentionality, acceptability, informativity, situationality and intertextuality" (Fauziah, 2015, p. 9) . In this paper, however, only intertextuality will be examined.

In spite of the existence of the views hinting at the fact that the notion of "intertextuality" is omnipresent in all literary works, it was not clearly established as it was by Julia Kristeva 
(1966). She was the first to use the term "Intertextuality" in 1966. In her pivotal work: "Word, Dialogue, Novel", Kristeva further substantiates the vague notion of "intertextuality" through attempting to combine the insights and major theories of both Bakhtin and Saussure. She brought the work of Bakhtin to light and further gave rise to her concept of intertextuality. In her essay "Word, Dialogue and Novel", Kristeva introduces the term "intertextuality" as "a dynamic text site in which relational processes and practices are the focus of analysis instead of static structures and products". She further argues that Intertextuality is shaped by the repetition and transformation of other textual structures (cited in Alfaro, 1996, p.268)

In his book, A Glossary of Literary terms, Abrams(1999) addresses intertextuality as follows: "The term intertextuality, popularized especially by Julia Kristeva, is used to signify the multiple ways in which any one literary text is made up of other texts, by means of its open or covert citations and allusions, its repetitions and transformations of the formal and substantive features of earlier texts, or simply its unavoidable participation in the common stock of linguistic and literary conventions and procedures that are "always already" in place and constitute the discourses into which we are born" (p.317). This definition explicitly posits that the concept of intertextuality is based on the reliance of literary content upon previous works, as suggested by Dastjerdi \& Sahebhonar (2008).

The correlation between the theory of intertextuality and the notion of genre has always been highly questionable. This relation is amply addressed in a study by (Duff, 2002). The Study primarily exhibits the various holds on the connection between the two notions. According to the study, genre is often listed as one constituent component of intertextuality in most definitions of intertextuality. The study further posits that some theorists deem genre as one aspect of the larger phenomenon of intertextuality, which, in turn, is "manifested in the forms of allusions, quotations, and influences" (p.54). Post to continued controversy on the notion of genre and the violent dismissal of posited theories and definitions of such notion, the theory of intertextuality appeared to offer a solution for the ongoing problem of the genre, better yet, the notion of genre was rather replaced by the theory of intertextuality. The assimilation of both items with one another, in fact, gave rise to theories debuting the existence of genre under the pretext of it being a superstition. On one hand, some theorists flatly refuted the coexistence of both intertextuality and genre. On the other hand there were valuable attempts to integrate notions of intertextuality with genre. The paper further casts light on Bakhtin posits intertextual relationships are always mediated by genres, entities that cannot be reduced to either mere synchrony or diachrony (Duff, 2002) . Kristeva, as well, holds the same view, she further argues that the notion of intertextuality embraces the process of genre-formation, to incorporate too the ad hoc genre-mixing and discourse-mixing performed by a particular text.Other intertextual theorists take the total opposite view of the latter. Roland Barthes, for instance, asserts that the theory of intertextuality does not recognize any division of genre (Duff, 2002). However, this research will address genre as one aspect of intertextuality.

After displaying all the possible theories on the connection between genre and intertextuality, one may ask how is the notion of intertextuality related to the discipline of translation. The axes along which translation deals with intertextuality are two. The first is the translation of intertextual material, especially in literary texts and the different strategies different translators 
used in dealing with this matter. Secondly, translators have sought to identify the clusters of features that are repetitively employed in the creation of a certain text type or genre. A research by Birsanu (2010) conducted on the relationship between both terms states that recent studies have revealed that translation discipline has gone beyond the limit of mere linguistic exchange. Birsanu (2010) has further explained that this discipline has expanded over the years to include a broader sense of the term "translation"; culture exchange, meaning transfer and interpretations on inter-systemic levels. According to another paper by Junhui,Qingshun(2014), "translation is now considered as a cross-language intertextual process which involves apprehending the source text and detecting the intertextual signals with the aid of sufficient historical and cultural knowledge in the source text' (p.44). In her paper Klimovich (2014) presents a number of studies conducted to illustrate the connection of intertextuality to translation and vice versa. One of the studies she refers to asserts that "translation is being understood not only as the interlinguistic phenomenon, but as the intertextual phenomenon (p. 256).

Intertextuality and translation are clearly manifested in the work of T.S Eliot, 1922, "The Waste Land". In her paper Birsanu (2011) discusses Eliot's approach to translation and intertextuality. She asserts that Eliot has used translation in his work as a compositional technique and embedded allusions belonging to various numbers of cultures as (French, Italian, and Latin) along with lines left in the original. The reader is thus required to exert a massive effort to fulfill two tasks at the same time. First, the reader must identify the initial settings of all embedded texts. Second, the reader must attempt to translate the meaning of the embedded texts and the surprising relocations. Due to such use, translation has become of high significance in the reading process, providing a vital key to deciphering a text

Many have probed into conceptualizing Intertextuality in written legal texts. Some claim that intertextuality in legal documents takes the form of legal terminologies, cross references, or citations, while others argue that legal texts are based on the precedent nature. Steel (1998) states that legal judgments are a species of works that strive to achieve technical precision, yet remain strongly literary in nature, therefore, applying intertextuality in such contexts is always possible. He further argues that legal judgments are overtly intertextual since they are strongly based on the concept of precedent. That is, any decision made by the court on the same issue, the previous decision must be followed. In other words, all judgments are laced with the intertexts of the previous judgments.

In his research Albi (2012) postulates that intertextuality in certain legal texts can only be achieved through references to points of law and procedural requirements (usually from Penal Codes and Rules of Procedure) and references to previous interactions, court hearings and documents. She further addresses two levels of intertextuality; one in the constant references to criminal codes and case law, while the other level of intertextuality is manifested in the name of court, case number, identification of parties and in the factual description of the case has gone through, usually found in the beginning of every document

Bhatia (1998) stresses that the omnipresence of intertextual tools in legal genres, normally serves the generic and disciplinary functions of making laws clear, precise, unambiguous and 
all-inclusive in addition to their text-coherence- function (as cited in Bhatia, 1998). According to Bhatia, legislative texts in particular display depth of intertextuality rarely found in any other texts. Such intertextuality signals a specific legal relationship between provisions in one legal document or other related document.

Other researchers like (Udina, 2018) postulates citation as an intertextual device that is omnipresent in all legal discourse. Legal citations, in particular, differ in their forms and analytical situations. They serve several functions and they can be referred to as cross-references. In her paper, Udina argues that "Citation relates the text of judgment to other legal texts such as Acts of Law, other court judgments, opinions and regulations and others" (p. 1090). She further notes that interrelations in legal texts are of paramount significance to construct the semantic framework of the text and impact the text structure. She posits that citations are intertextual devices that perform various semantic and pragmatic functions. These functions are important in production and in text understanding. Udina views citation as an explicit manifestation of intertextuality in any legal texts and normally serves multifunctional purposes

According to Galdia(2009), intertextuality is common in law as it is common in all literary works. However, it is sometimes less obvious than it is in literature. In his "Legal Linguistics", he asserts that sonnets and short stories resemble codes and statutes with their different origins from around the world. This makes intertextual relations equally pervade the content of all legal texts.

As far as cross references are concerned, a study was carried out by Mattila to probe into all different techniques adopted in different countries to signal out one type of intertextuality in court decisions. The author further presents the many technical ways utilized to place references to other texts in court decisions (Mattila, 14).

Based on the above studies, we may say that intertextuality in legal texts has been discussed narrowly. Bhatia for instance, has touched upon several tools that he posits as intertextual tools in legal texts. Other studies expanded the notion of intertextuality in legal texts to include citations and quotation as salient intertextual tools in almost every legal text in general, and judicial documents in particular.

\subsection{Objectives}

This research is set to examine all the different angles of intertextuality in legislative and private legal texts which were never addressed or touched upon previously. Probing such a notion in both text types will certainly result in providing solid guidelines to legal translation pedagogy and tangible gains for legal translation practitioners. To this end, this research aims at examining intertextuality in these texts through analyzing different Arabic and English texts in both genres. The notion of intertextuality in this paper shall encompass lexical expressions, syntactic patterns, formulaic language, recurrence of segments and rhetorical organization concerning register conventions and genre analysis. By lexical expressions we mean the most repeated words in both legislative and private texts. Also, the thesis will focus on the generic analysis of rhetorical organization in legislative texts and private legal text. The paper will 
further examine all the issues related to genre through studying closely the rhetorical organization as well as the traces of texts or parts of them in other texts. The expanded notion of intertextuality in this paper will also include the omnipresence of repetition on different levels: lexical, syntactical, formulaic and organizational. Finally, this thesis will bring to light the paramount significance of studying the constituent components of intertextuality in legal texts to translation pedagogy and translation practices.

This paper is an attempt to answer three questions. These questions are:

- What is intertextuality from a translator's perspective?

- How is it demonstrated in legislative and private legal texts?

- In what way can intertextuality be used in text analysis, translation and translation pedagogy?

This study will only focus on two genres: private legal texts (power of attorney, lease contracts, employment contracts) and legislative texts (e.g. decrees, executive order). Therefore, it will not include judicial texts, or legal scholarly texts. It will also be restricted to a specific number of texts though the results are most likely to be replicated if applied to other text within the same genre.

\section{Method}

\subsection{Introduction}

A quantitative approach was adopted by this paper in order to provide evidence-based generalizations about the different forms of intertextuality, which are, deliberately or inadvertently, omnipresent in different legal spheres, specifically, legislative and private legal texts.

\subsection{Samples}

The samples were derived from different origins to cast light on the similarities and differences in the occurrence of implicit and explicit intertextual figures in legislative and private legal texts. The study was conducted on English and Arabic Power of Attorneys documents, Lease Agreements and Employment Agreements. The English Private legal texts were collected from different countries as shown below: Power of Attorneys from:

- USA

- South Africa

- UK

Lease Agrements:

- USA

- Australia

- UK 


\section{Macrothink}

Employment Agreements

- USA

- Canada

- UK

The Arabic legal documents were also collected from different countries as outlined below:

Power of Attorneys from

- UAE

- Jordan

- Lebanon

Lease Agreements from:

- Yemen

- Palestine

- Egypt

Employment Agreements from

- UAE

- Syria

- Palestine

As for the legislative texts, the study was conducted on:

- UAE Labor Law

- UAE Decree

- Executive Order

\subsection{Procedure}

- $\quad$ Collecting a sufficient number of samples to conduct a proper study;(5 each)

- Comparing the frequency of specialized legal terms occurrences in private legal texts and the legislative text;

- $\quad$ Examining salient grammatical features in private legal texts ;

○ (Passive sentences, form of verbs, obligatory models, and the frequent occurrences of syntactic discontinuities.)

- $\quad$ Studying the rhetorical organization of text types; 
- Investigating the standard forms of employment contract. That is, the standard sequence and occurrences of the followings: preamble, nature of work, salary, probation periods, vacations, term of employments, and so forth.

\section{Findings}

The notion of intertextuality in legislative and private texts has been demonstrated in three different forms based on the findings obtained through the analytical and statistical study conducted on the instruments understudy.

- This study revealed that Power of Attorneys include integral elements of a particular order in both English and Arabic legal writing. These elements incorporate the statement of delegation to the agent "I the undersigned do hereby appoint" followed by the information of the agent, as in the date of birth and its current address, powers delegated to the latter, date of signing the instrument and finally appear the signatures of the Principle, the Agent and the witnesses. A further novel finding is that Power of attorneys in both Arabic and English appear to share roughly the same template despite the difference of origin.

With respect to the rhetorical organization of Arabic and English Power of Attorney, the data generated from this research paper suggest that the elements of both Arabic and English Power of Attorneys are arranged in a perceptible order. English Power of Attorneys, for instance, embarks on the title followed by preamble, main body and finally appears the signatures of the concerned parties. The results also demonstrate that the preambles of English Power of Attorneys normally incorporate the personal details of the principle and the statement of delegation by the same. The main body includes the particulars of the powers delegated to the agent of which are listed numerically, statement ratifying the delegated powers by the principle and finally concluded with the signatures of the concerned parties.

In parallel, Arabic Power of Attorneys has the same arrangement of elements. The constituent components of each element are roughly the same, except for statements ratifying the delegated power by the principle. The only major difference between the two rhetorical organizations is the listing pattern of the delegated powers. English Power of Attorneys seems to adopt the numerical pattern to list the powers, while in Arabic Power of Attorneys, the delegated powers are normally drafted in one long paragraph, of which sentences are separated by the letter " 9 ". Unlike English legal writing, Arabic writing in general, and legal writing in particular, tend to make abundant use of explicit connecters, in order to express semantic relationship between utterances.

- The Findings of lease agreements in terms of its rhetorical organization are quite revealing. An English Lease agreement typically includes the basic terms of tenancy which generally comprise the name of tenants, term of tenancy, rental amounts, limits on occupancy, deposits and fees, repairs and maintenance, entry to rental property, restrictions on Tenant's illegal activities, pets and other restrictions. As far as the terms of lease Agreements are concerned, terms may differ from one Lease Agreement to another. Nonetheless, terms like rental amount, deposits and fees, uses of property, rent term, and repairs and maintenance appear to be fixed in all the Lease Agreements understudy irrespective of their origins. As to the rhetorical 
organization of lease agreement, it's noted that the samples understudy do not follow a uniform model of lease agreements, nor do they have a fixed order of items internally. Nevertheless, the examined samples commonly start with preambles, followed by terms and end with signatures.

The same holds true for Arabic Lease agreements. The findings suggest that the examined samples commonly share fixed clauses, such as rental amount, the leased premises, fees and deposits, and subletting. They all start with a preamble, followed by the stipulated articles, and concluded with the signatures of the concerned parties.

These results lead to the same conclusion in terms of English and Arabic Employment agreement. Employment agreements share the same rhetorical organization even though the lists of heading vary among the examined samples. Take for instance, English Employment, though culled from different origin they shared several articles of which instances occurred in the entire instruments understudy, such as (Employment, term, vacation, remuneration, termination and severability). This also applies to Arabic Employment agreements. The instruments start with a preamble, followed by the promulgated clauses and articles and concluded with the signature of Employer and Employee. This leads us to conclude that these sorts of item arrangement appear to be typical among all private legal texts understudy.

- Legislative texts such as Decrees and Executive Order follow a strict format and a predetermined structure. This is attributed to the fact that such documents are official proclamations issued by the judicial bodies, and having the force of law. This was further substantiated in UAE Decree and UAE labor law, that share an identical rhetorical organization with a remarkable difference in terms of the arrangement of the enacted clauses. They both commence with law number, year and topic, followed by a brief description on the source of authority issuing the decree. It may be convenient to mention that these particular instruments encompass explicit intertextual figures demonstrated in the form of references. A simple instance is the following "' The United Arab Emirates Federal Decree-Law No (8) of 2017 on Value Added Tax Law'. Such reference is primarily employed to add depth to the legal text based on the reader's prior knowledge and understanding of the United Arab Emirates federal Decree and so forth. The rhetorical organization of Executive Order, however, slightly differs from that of UAE Decrees and UAE Labor law. It is commenced with Executive order Number, date and year but in the second place comes the topic and in third place comes the source of authority and finally it is concluded with the place and date of issuance. It is worth mentioning that referencing is commonly utilized in legislative texts to contribute to the meaning of the provision.

- The results of salient syntactic features in contractual agreements cast light on findings of paramount significance to translation pedagogy in particular. The intertextual figure of several syntactic features in lease agreements, Power of Attorneys, and employment agreements will certainly pave the way before beginner translators to adopt efficient translation methods when rendering private legal texts.

As for the most prominent syntactic features in English Power of Attorneys, it is found that infinitives constitute a major constituent component of English Power of Attorneys. That is to 
say, the powers delegated to the agent to manage the business affairs, are often written in the infinitive form to express the verbal ideas in its simplest form. While the form of verbs used to draft a Power of Attorneys is mostly in simple present tense form to express actions happening unceasingly. Almost half of English Power of Attorneys makes heavy use of simple present tense, better known as present indefinite, to be in line with the content of the legal text. Furthermore, the prominence of coordinating conjunctions in all Power of Attorneys understudy are also quite striking. The omnipresence of words connecting two elements of equal syntactical value lead us to conclude that coordinating conjunctions are commonly incorporated in English Power of Attorneys.

The results also show that there are certain syntactic features of insignificant occurrences. It was found that passivization and modal verbs are mildly utilized in Power of Attorneys. This could be attributed to the fact that their abundant use may violate the main drafting requirements, which is granting equitable access to legal information for a layperson, besides legal experts.

With Respect to Arabic Power of Attorneys, verbal nouns and coordinating conjunctions constitute the majority of such legal documents. The Verbal noun, better known as "المصدر", is a noun that originates from a verb, which encompasses the action and has no doer or time information. The result shows that Arabic Power of Attorneys make abundant use of verbal nouns to shed light on the powers delegated to the agent. The prominence of coordinating conjunctions is also quite remarkable. It is quite evident that Arabic Power of Attorneys makes a heavy use of the conjunctions to connect two equivalent sentences, phrases and even words. As far as the form of verbs is concerned, Arabic Power of Attorneys employ simple present to express action happening regularly in the same manner in English Power of Attorneys. The results indicate that all covered samples utilized simple present to express actions happening unceasingly, in order to be consistent with the purpose of acting on one's behalf for indefinite time.

- As for the Lease Agreements, the results show that English Lease Agreements, in particular, make abundant use of modality. The abundant use of modal verbs in this particular sub-legal text ascribes to the drafting requirements of expressing conditions, permissions, and obligations. The result shows that the most used modals in the examined lease agreements are: shall, will and may. Shall, in particular, is extremely frequent in legal discourse. One of the suggested implications of the verb shall is that it is used to express obligation and imply futurity, Triebel (2009). The semantic function of this modal verb in lease agreements includes both obligation and implies futurity, and this primarily depends on its occurrence within a context. The second modal of highest frequency is will. Will is mainly used to express temporal meaning, prediction, volition, and habitual activity. Nonetheless, the root meaning of "will" in the lease agreements understudy is deontic as it lays obligation on both the lesser and the lessee. As for "may", It is the third most used modal in lease agreements. It is largely used to express possibility and permission, and this holds true for the all the lease agreements understudy. 
With respect to the form of verbs, Lease agreements encompass a variety of verbs such as passivization, future tense, and simple present. It is found that such contractual agreements utilize passivization to mostly obscure agent and intensify the importance of action itself. Simple presents and future tense are broadly used in the same range to cast light on obligations and unceasingly happening action towards such obligations.

As far as modal verbs are concerned in Arabic Lease agreements, the study reveals that Arabic legal writing does not make much use of modal verbs, thus this particular feature is deemed to be of minor importance when drafting an Arab Lease Agreement. Nonetheless, the meaning of modal verbs expressing obligations is achieved via the main verb of the sentence, which mainly occurs in simple present tense form. Whereas modal verbs expressing possibility and permissions are frequently utilized as " "قدوز" “" The rest of modal verbs hardly occurred in the Arabic Lease Agreements understudy. Instead, the results indicate that Arabic lease agreements, in particular, make abundant use of simple present to primarily express the notion of obligation.

The results of this study also show that English employment agreements employ central modal verbs to express notions of obligations, possibility, and permission, such as contained in Lease Agreements. Passivization is also used roughly in the same range as that in Lease agreements to obscure agents and focus on actions. However, the use of future tense in English Employment agreements differs from that in lease agreements. According to the results achieved, Employment agreements make greater use of future tense than that of Lease Agreements to mainly express the obligations laid on the Employer and Employee.

With respect to Arabic Employment agreements, the prominence of simple present is quite striking. This is attributed to the fact that Arabic legal discourse largely uses simple present instead of the modal verb "shall" to express the notion of obligation. This is particularly true for all the Arabic Employment agreements understudy. It is also found that Arabic Employment agreements employ verbal nouns heavily to express actions with no periods. The results also outline the prominence of coordinating conjunction in Arabic Lease agreements. It is now quite remarkable that simple presents, verbal nouns, and coordinating conjunctions are the major constituent components of Arabic Employment Agreements.

As far as the repeated terminologies are concerened, it was observed that terms like "do hereby", ' 'authorize', ' 'in my name', ' 'on my behalf', ' 'act', ' 'undersigned" are the most recurrent terms in both English and Arabic Power of attorneys. While terms including "parties', ''lesser', lessee', 'rent', 'security deposits"' and 'notice' are the terms that constitute the majority of Arabic and English Lease agreements. As For the English and Arabic Employment agreements, terms like "party", 'Employer', 'Employee', 'salary', ‘, Termination', 'contract', and terms appeared to be the most recurrent terms in all employment agreements understudy.

To further substantiate the depth of intertextual figures in private legal texts, the generated data cast light on a standardized language in contracts, also known as the boilerplate. This term normally refers to the clauses that appear at the end of the agreements because they do not fit anywhere else in the contractual agreements. The consensus has been that 
boilerplates constitute an integral part of contractual agreements in particular, as they state and regulate rules in terms of disputes, governing laws, enforceable laws and so forth. These findings further documented that intertextuality can be produced using a variety of functions including the standardized language in contracts, as it serves in making law precise and all-inclusive. Prior studies on the depth of intertextual devices in private legal texts have restricted the omnipresence of intertextuality to few several aspects, of which are the citation and quotation. However, the findings in this paper confirm that intertextual figures can be broadened to include the standardized language of contracts, also known as boilerplates, as they can be reused in different contractual agreements without significant changes to the origin.

\section{Conclusion and Recommendations}

This current study has further proven that legislative and private legal texts display a variety and depth of intertextual figures rarely noticed in other spheres. The notion of intertextuality was demonstrated through unified models, rhetorical organizations, standardized language, recurrent terms and prominent syntactic features of the contractual agreements and the legislative instruments understudy.

Unified modal, rhetorical organization and standardized language of contracts and legislative texts were investigated in terms of stipulated articles and the arrangement of items. The results showed that contractual agreements share a roughly similar templates and rhetorical organization. The same holds true for UAE decree, UAE labor and Executive order. Another interesting finding is that contractual agreements normally share a set of terminologies that occur in nearly identical clauses and articles, in addition to certain prominent syntactic features among the instruments that were rather remarkable. Such as the abundant use of modal verbs in English Lease Agreements and Employment agreements compared to their Arabic Counterparts, and the heavy use of infinitives in English Power of Attorneys

The significance of this study lies in the fact that it is the first study that attempts to broaden the notion of intertextuality beyond citation and quotation. The results of this research paper contribute to the discipline of legal translation in both English and Arabic languages. The results are of great help for translation trainees and practitioners in comprehending and analyzing the templates, the syntactic, and the semantic functions of contractual agreements and legislative texts.

Furthermore, these results have several implications for attorneys, paralegals, and legal consultants to help them draft such instruments from scratch.

- The results of the analysis of rhetorical organization, recurrent terminologies, and prominent syntactic features of contractual agreements should be outlined in legal translation courses.

The notion of intertextuality should often be incorporated in the legal sphere through conducting extensive research examining other possible intertextual figures, in order for the students and translators to be familiarized with the omnipresence of the notion, whether deliberately or inadvertently, in the discipline of legal translation. 
Translators should be well aware of remarkable differences and similarities between the syntactic features of English and Arabic legal writing, in order to produce a proper translation that conforms with the target text syntactic system.

Students and translators should be aware that Arabic legal writing favors active to passive voice in contractual agreements, as the results of the analysis carried out in this study.

There exist certain terminologies that appear to be universal. Students and translators should get acquainted with their frequency of occurrences and instances, in order to produce an accurate translation for the recurrent terminologies in both languages.

- $\quad$ Translators and legal writers should realize the similarities of rhetorical organization of contractual agreements in both English and Arabic and follow the same when rendering and drafting the contractual agreement instruments.

Translators should realize the abundant use of references utilized in legislative texts to signal authority. Legal writers should also be well aware of the predetermined structure of legislative texts.

Arabic legal translation and language lack statically based studies conducted on prominent syntactic features and figures of intertextuality in Arabic contractual lease agreements. Researchers should focus on conducting extensive studies to help translators adopt efficient methods when rendering legal texts.

\section{References}

Abrams, M. H. (1999). A Glossary of Literary terms (7th ed.).

Ahmed, M. F. (2010). An intertextual approach to Arabic-English translation. College of Basic Education Researchers Journal, 10(1), 505-527.

Albi, A. B. (2013). A genre analysis approach to the study of the translation of court documents. Linguistica Antverpiensia. New Series-Themes in Translation Studies, (12).

Alfaro, M. J. M. (1996). Intertextuality: Origins and development of the concept. Atlantis, 268-285.

Allen, G. (2011). Intertextuality. Routledge: London. https://doi.org/10.4324/9780203829455

Askehave, I., \& Nielsen, A. (2004). Web mediated genres- a challenge to traditional genre theory. Denmark.

Beaugrande, R. D., \& Dressler, W. U. (1981). Introduction to text linguistics. London and New York: Longman. https://doi.org/10.4324/9781315835839

Beaugrande, R., \& Dressler, W. (1981). Text Linguistics. New York: Longman.

Bhatia, V. (2004). Worlds of written discourse: A genre-based view. A\&C Black.

Bhatia, V. K. (1998). Intertextuality in legal discourse. Language Teacher-Kyoto-Jalt, 22, 13-18. 
Bhatia, V. K. (2014). Analysing genre: Language use in professional settings. Routledge. https://doi.org/10.4324/9781315844992

Birsanu, R. (2010). Intertextuality as Translation in TS. Eliot's The Waste Land. Sendebar, 21, 21-35.

Birsanu, R. (2011). TS Eliot and the modernist approach to translation. Scientia Traductionis, (9), 179-190. https://doi.org/10.5007/1980-4237.2011n9p179

Cao, D. (2007). Translating law. Multilingual Matters. https://doi.org/10.21832/9781853599552

Chaudhuri, R. (2015). The Rustle of Language. In Rabindranath Tagore in the 21st Century (pp. 15-23). Springer, New Delhi. https://doi.org/10.1007/978-81-322-2038-1_2

Dastjerdi, H., \& Sahebhonar, S. (2008). Lost in translation: An intertextual study of personal proper-name allusions. Across Languages and Cultures, 9(1), 41-55. https://doi.org/10.1556/Acr.9.2008.1.3

De Saussure, F., \& Baskin, W. (2011). Course in general linguistics [1916]. London: Duckworth.

Delammermore, A. (2018). Intertextuality in Eliot's The Waste Land. Retrieved December 20, 2020, from http://courses.utulsa.edu/wwi/?q=content/intertextuality-eliots-waste-land

Devitt, A. (1991). Intertextuality in tax accounting: generic, referential, and functional. In C. Bazerman, \& J. Paradis (Eds.), Textual dynamics of the professions: historical and contemporary studies of writing in professional communities (pp. 336-357). Madison: University of Wisconsin Press.

Duff, D. (2002). Intertextuality versus genre theory: bakhtin, kristeva and the question of genre. Paragraph, 25(1), 54-73. https://doi.org/10.3366/jsp.2002.25.1.54

Federal Register. (2012). Executive Order 13597 of January 19, 2012. Retrieved January 24, 2012, from https://www.govinfo.gov/content/pkg/FR-2012-01-24/pdf/2012-1568.pdf

Galdia, M. (2009). Legal linguistics. Peter Lang.

$\begin{array}{llll}\text { Intertextuality. } & \text { (n.d). } & \text { Retrieved }\end{array}$ http://www.basicknowledge101.com/pdf/literacy/Intertextuality.pdf

Klimovich, N. V. (2014). Phenomenon of intertextuality in translation studies.

Krist, D. (2018). Boilerplate clauses in legal documents. Retrieved May 1, 2018, from https://www.lawdepot.com/blog/boilerplate-clauses-in-a-legal-document/

Kristeva, J. (1986). The kristeva reader. Columbia University Press.

Mattila, H. E. (2011). Cross-references in court decisions a study in comparative legal linguistics. Lapland Law Review. Law and Language in Partnership and Conflict. Retrieved March 20, 2018, from http://www.ulapland.fi/InEnglish/Units/Faculty-of-Law/Research/Lapland-Law-Review/Abo ut-the-Journal 


\section{Macrothink}

International Journal of Linguistics

ISSN 1948-5425

2021, Vol. 13, No. 1

Mikhchi, H. H. (2011). Standards of Textuality. Journal of Universal Language, 12(1), 47-74. https://doi.org/10.22425/jul.2011.12.1.47

Nagy, T. (2012). Law, literature and intertextuality. Acta Juridica Hungarica, 53(1), 62-71. https://doi.org/10.1556/AJur.53.2012.1.6

Olga, K. (2017). Semantics of the verb shall in legal discourse. Irkutsk State Technical $\begin{array}{lllll}\text { University. } & \text { Retrieved } & \text { December } & \text { 20, } & \text { from }\end{array}$ https://www.researchgate.net/publication/321488615_Semantics_of_the_verb_shall_in_legal _discourse

Steel, A. (1998). Intertextuality and legal judgments. Macarthur L. Rev., 2, 87.stim, Richard. Common Boilerplate Provisions in Contracts. Retrieved from https://www.nolo.com/legal-encyclopedia/common-boilerplate-provisions-contracts-32654.ht $\mathrm{ml}$

Swales, J. (1990). Genre analysis: English in academic and research settings. Cambridge University Press.

Thomas, E. A. (2014). Contract law: The importance of Standard 'Boilerplate' clauses in $\begin{array}{llll}\text { agreements. } & \text { Retrieved } & \text { September } & \text { 2014, from }\end{array}$ http://www.vanhuyssteens.co.za/newsroom/item/39-contract-law-the-importance-of-standard -boilerplate-clauses-in-agreements

Thomson, R. (2016). Boilerplate clauses by practical law corporate \& securities and practical law commercial transactions. Retrieved from https://blog.richmond.edu/lawe759/files/2016/08/Boilerplate-Clauses.doc.pdf

Trask, R. L. (2000). The penguin dictionary of english grammar.

Udina, N. (2018). Citation as intertextual device in legal discourse.

Wu, J., \& He, Q. (2014). Poetry translation: An intertextuality approach. Studies in Literature and Language, 9(1), 43.

Zelenka, R. (2013). Modality in the language of legal documents. Tomas Bata University.

Zengin, M. (2016). An Introduction to intertextuality as a literary theory: Definitions, axioms and the originators. Pamukkale University Journal of Social Science Institute, 2016(50), 299-327. https://doi.org/10.5505/pausbed.2016.96729

\section{Copyrights}

Copyright for this article is retained by the author(s), with first publication rights granted to the journal.

This is an open-access article distributed under the terms and conditions of the Creative Commons Attribution license (http://creativecommons.org/licenses/by/4.0/) 